\title{
Programmed Death-ligand 1 Expression Analysis for Non-small Cell Lung Cancer in Tissues Sampled Using Different Methods
}

\section{Farkı Yöntemlerle Örneklenen Akciğer Küçük Hücreli Dışı Karsinom Dokularında Programlı Ölüm Ligandı 1 Ekspresyon Analizi}

\author{
(1) Halide Nur Ürer, (1) Mehmet Zeki Günlüoğlu* , (D) Levent Cansever**, (1) Mehmet Ali Bedirhan** \\ University of Health Sciences Turkey, Yedikule Chest Diseases and Thoracic Surgery Training and Research Hospital, Clinic of Medical \\ Pathology, Istanbul, Turkey \\ *Medipol Mega University Hospital, Clinic of Thoracic Surgery, istanbul, Turkey \\ ** University of Health Sciences Turkey, Yedikule Chest Diseases and Thoracic Surgery Training and Research Hospital, Clinic of Thoracic \\ Surgery, istanbul, Turkey
}

\section{Abstract}

\begin{abstract}
Aim: This study aims at investigating the concordance of programmed death-ligand 1 (PD-L1) expression in non-small cell cancer tissues that have been sampled using different methods and its relationship with the pathologic parameters of tumors.

Methods: PD-L1 expression assays were made on the cell blocks taken using fine needle aspiration, the small tissue samples representing endoscopic biopsy and the large tissue samples representing the resected tumor taken from the tumors of 100 subjects diagnosed with non-small cell lung cancer; their percentage values were evaluated and their groups were determined based on these values.
\end{abstract}

Results: The average difference in expression rates found through different sampling methods was close to 0 , and the values of such differences changed mostly in a narrow range. In paired comparisons, a good level of concordance was observed between all the sampling methods. The values were 0.8865 (SE: 0.0306, Cl: 0.8264-0.9466) in the comparison of tumor tissue (TT) and small biopsy (SB): 0.8637, (SE: 0.033, Cl: 0.7989 0.9285 ) TT to cell block (CB): 0.8916, (SE: 0.0272, Cl: 0.8383$0.9449)$ SB tissue to the CB.

Conclusion: Therefore, it can be concluded that the PD-L1 expression does not differ between the tissues sampled through various methods in non-small cell lung cancers.

Keywords: Non-small cell carcinoma, PD-L-1, cell block, different expression
Öz

Amaç: Çalışmada amacımız farklı yöntemlerle örneklenmiş küçük hücreli dışı karsinomda programmed death-ligand 1 (PDL1) ekspresyon uyumunu ve tümör patolojik parametrelerle ilişkisini araştırmaktır.

Yöntemler: Küçük hücreli dışı akciğer karsinom tanısı alan 100 olgunun tümöründen ince iğne aspirasyonu hücre bloğu, endoskopik biyopsiyi temsil eden küçük doku ve rezeksiyon tümör temsil eden büyük doku örneğinde PD-L1 ekspresyon tayini yapılıp yüzde değerleri ve buna göre grupları değerlendirildi.

Bulgular: Örnekleme yöntemleri tarafından saptanmış ekspresyon oranlarının ortalama farkının 0’a yakın olduğu gibi, fark değerlerinin, büyük oranda, dar uyum içinde olduğu bulundu. İkişerli karşılaştırmalarda, tüm örnekleme yöntemleri arasında, PD-L1 ekspresyon oranı açısından iyi düzeyde uyum olduğu izlendi. Tümör dokusu-biyopsi dokusu karşılaştırmasında 0,8865 (SE: 0,0306, Cl: 0,8264-0,9466), tümör dokusu-hücre bloğunda 0,8637 (SE: 0,033, Cl: 0,7989-0,9285); biyopsi dokusuhücre bloğunda 0,8916 (SE: 0,0272, Cl: 0,8383-0,9449) idi.

Sonuç: Sonuçta akciğerin küçük hücreli dışı karsinomlarında PDL1 ekspresyonu farklı yöntemlerle örneklenmiş dokular arasında fark göstermemektedir.

Anahtar Sözcükler: Küçük hücreli dışı karsinom, PD-L1, hücre bloğu, farklı yöntemler
Address for Correspondence/Yazışma Adresi: Halide Nur Ürer, University of Health Sciences Turkey, Yedikule Chest Diseases and Thoracic Surgery Training and Research Hospital, Clinic of Medical Pathology, İstanbul, Turkey

Phone: +90 5052659365 E-mail: nururer@gmail.com ORCID: orcid.org/0000-0002-0549-9969 Received/Geliş Tarihi: 18 October 2019 Accepted/Kabul Tarihi: 5 January 2020

The study has previously been presented as an oral presentation at $29^{\text {th }}$ National Pathology Congress in Turkey at 23-26 October 2018.
Copyright 2020 by The Medical Bulletin of istanbul Haseki Training and Research Hospital The Medical Bulletin of Haseki published by Galenos Yayınevi. -Telif Hakkı 2020 İstanbul Haseki Eğitim ve Araştırma Hastanesi Haseki Tıp Bülteni, Galenos Yayınevi tarafından yayınlanmıştır. 


\section{Introduction}

The treatments of non-small cell lung cancer have shown fast improvements in recent years, the most outstanding being cancer immunotherapy $(1,2)$. In carcinogenesis, suppression of the host immune system by tumor cells facilitates tumor proliferation. Blocking the programmed death-ligand 1 (PD-L1) receptors on the cell surface that create immune tolerance is an activating cancer immunotherapy method (3). Removal of the blockage triggers $T$ lymphocyte immunization against cancer cells.

The decision for immunotherapy is made upon evidencing the presence of a PD-L1 expression in the tissue. The samples obtained using various methods can be used to identify the ligand. Moreover, the distribution of PD-L1 expression in tissues is variable in non-small cell cancers (4). This raises the question whether the expression values of different intervention methods used in the diagnosis of cancer have the same proliferation value.

This study aims at investigating the concordance of PD-L1 expressions in non-small cell cancer tissues sampled using different methods and its relationship with the pathologic parameters of tumors.

\section{Methods}

This study was conducted in the Department of Pathology in Yedikule Chest Diseases and Thoracic Surgery Training and Research Hospital. One hundred subjects diagnosed with non-small cell lung cancer based on the preoperative or intraoperative frozen sections were enrolled in the study.

The tissues whose routine pathological macroscopic assessments and samplings in their pulmonary tumor resection material had been completed were included in this study. Tumors larger than $2.9 \mathrm{~cm}$ and diagnosed with non-small cell lung cancer were the inclusion criteria. Patients with a tumor $\leq 2.9 \mathrm{~cm}$, those with undetectable tumor tissue (TT) after neoadjuvant therapy and those diagnosed with a disease other than non-small cell cancer were excluded.

First, cell block (CB) were sampled using fine needle aspiration from the residual tumor that remained on the resection and was not yet involved in buffered formalin fixation. Secondly, 2-5 pieces of tissue 2-3 $\mathrm{mm}$ in diameter, representing endoscopic small biopsy (SB) were sampled from the residual tissue. Finally, after the completion of the macroscopic TT sampling, a piece of TT at least 1-2 $\mathrm{cm}^{2}$ in diameter and 2-3 mm in thickness was taken.

The demographic characteristics of the subjects, anatomic resection types, tumor diameters, histopathological diagnoses, tumor diameters, lymphovascular involvements, peritumoral lymphocytic inflammation and lymph node metastasis statuses (no metastasis $=\mathrm{NO}$, inter-and intralobular lymph node metastasis=N1, mediastinal unilateral lymph node metastasis=N2) were explored.

Study designing has been approved by Local Ethical Committe of University of Health Sciences, İstanbul Training and Research Hospital Ethics Committee. The study protocol number and date are 1058/04.08.2017.

\section{Immunohistochemical Analysis}

A commercial product approved for lung cancer was chosen for the immunohistochemical analysis of PD-L1 (5). After deparaffinization, the slides were subjected to immunohistochemical analysis using the PD-L1 antibody (SP263 Roche/Ventana) and an Optiview DAB IHC detection kit (Roche/Ventana) was used as a universal kit.

While assessing the PD-L1 expression, complete or incomplete membranous staining was accepted as a positive value. The intensity of staining was not considered in this assessment. The tumor cells in the entire area of each sample were counted. Further, the tumor cells exhibiting PD-L1 expression were counted; and PD-L1 percentage value was found based on the percentage value, they were grouped as none (0), less than 1 , equal to or greater than 1 , less than 5 , equal to or greater than 5 , less than 10 , equal to or greater than 10 , less than 50 and equal to or greater than 50 .

\section{Statistical Analysis}

The analyses were conducted using the $\mathrm{R}$ software and interactive software. The one-sample t-test was used to compare the mean values. To demonstrate the concordance, Lin's concordance correlation coefficient and Cronbach's alpha coefficient were used for measured variables and weighted kappa and Fleiss' kappa values for ordinal variables. To show correlations, Pearson's correlation coefficient was used for measurable variables and Spearman's correlation coefficient for ordinal variables. Additionally, any probability level less than 0.05 was considered significant.

\section{Results}

A total of 100 patients had a preoperative or intraoperative diagnosis of non-small cell cancer. The demographic characteristics and surgical data of the subjects and histopathological findings are shown in Table 1.

The surgical procedures included 70 lobectomies, four bilobectomies, 26 pneumonectomy, four chest wall resections and one carinal sleeve resection.

The PD-L1 expression was found to be less than 1 in 35 subjects (35\%) and 1 or more in 65 (65\%) (Figure 1). The PD-L1 expression value groups and histopathological tumor distribution are shown in Table 2. 
The general distribution of PD-L1 expression (Figure 2), and its distribution in squamous cell carcinoma (Figure 3) and in adenocarcinoma (Figure 4), were shown. Moreover, its highest value among TT, SB and CB were considered.

The least PD-L1 expression was found in the other carcinomas group. No expression was found in mucinous adenocarcinoma, large-cell neuroendocrine carcinoma and

\begin{tabular}{|c|c|}
\hline Total cases & $\mathrm{n}=100$ \\
\hline Female/Male & $15 / 85$ \\
\hline Age & $60.2(39-78)$ \\
\hline \multicolumn{2}{|l|}{ Histopathological diagnosis } \\
\hline Squamous cell carcinoma & 58 \\
\hline Keratinizing squamous cell carcinoma & 40 \\
\hline Nonkeratinizing squamous cell carcinoma & 17 \\
\hline Basaloid squamous cell carcinoma & 1 \\
\hline Adenocarcinoma & 31 \\
\hline Mucinous adenocarcinoma & 3 \\
\hline Adenosquamous cell carcinoma & 1 \\
\hline Carcinoid tumor & 4 \\
\hline Typical carcinoid tumor & 3 \\
\hline Atypical carcinoid tumor & 1 \\
\hline Large-cell neuroendocrine carcinoma & 1 \\
\hline Pleomorphic carcinoma & 2 \\
\hline Tumor diameter $(\mathrm{cm})$ & $2.9-11$ \\
\hline \multicolumn{2}{|l|}{ Lymphovascular invasion } \\
\hline Positive/Negative & $71 / 29$ \\
\hline \multicolumn{2}{|l|}{ Peritumoral lymphocytic inflammations } \\
\hline No/minimal/medium/intense & $43 / 30 / 20 / 7$ \\
\hline \multicolumn{2}{|l|}{ Lymph nodal metastasis } \\
\hline No/N1/N2 & $56 / 33 / 11$ \\
\hline
\end{tabular}

typical and atypical carcinoid tumors. The expression was found to be $5-10 \%$ in adenosquamous cell carcinoma and over $50 \%$ in one of the pleomorphic carcinomas. It was limited only to the carcinoma component in that tumor. Its value was 0 in the other pleomorphic carcinoma.

The concordance of the PD-L1 expression percentage values was explored in the samples of TT, SB and CB.

Assessment of the expression values showed that $39 \%$ of the tumors expressed PD-L1 at a low level and $46 \%$ of them at a high level in the TT; a moderate level of expression was hardly encountered (Table 3).

\section{Discussion}

The concordances of the PD-L1 expression values obtained with the three sampling methods were compared. A graphical evaluation of the concordance (Figure 5), showed that the expression values found by the sampling methods were very close to each other in each paired comparison as seen in the scatter plots, and for this reason, the best fit line determined for the distribution

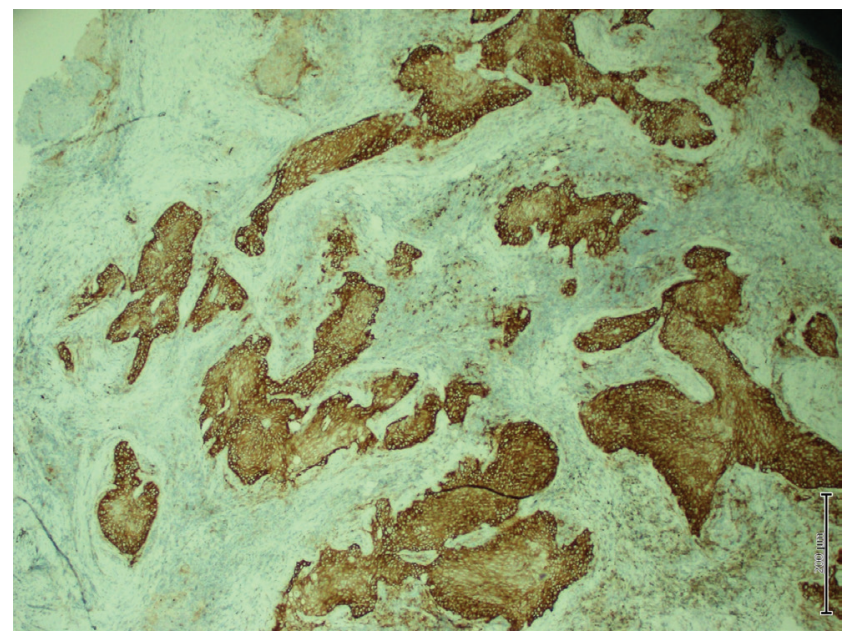

Figure 1. Programmed death-ligand 1 expression in small biopsy

Table 2. Distribution of programmed death-ligand 1 expression

\begin{tabular}{|c|c|c|c|c|c|c|c|c|}
\hline Histologic type & $0(\%)$ & $<1(\%)$ & $\geq 1<5(\%)$ & $\geq 5<10(\%)$ & $\geq 10<50(\%)$ & $>50(\%)$ & Total (\%) & $\begin{array}{l}\text { Discordant case } \\
\text { number }\end{array}$ \\
\hline Squamous cell carcinoma & 8 & 6 & 1 & 2 & 10 & 15 & 58 & 16 \\
\hline Adenocarcinoma & 7 & 5 & 1 & 0 & 6 & 6 & 31 & 6 \\
\hline Mucinous adenocarcinoma & 3 & - & - & - & - & - & 3 & - \\
\hline Adenosquamous cell carsinoma & - & - & - & - & - & - & 1 & 1 \\
\hline Typical carcinoid tumor & 3 & - & - & - & - & - & 3 & - \\
\hline Atypical carcinoid tumor & 1 & - & - & - & - & - & 1 & - \\
\hline $\begin{array}{l}\text { Large-cell neuroendocrine } \\
\text { carcinoma }\end{array}$ & 1 & - & - & - & - & - & 1 & - \\
\hline Pleomorphic carcinoma & 1 & - & - & - & - & 1 & 2 & - \\
\hline Total & 24 & 11 & 2 & 2 & 16 & 22 & 77 & 23 \\
\hline
\end{tabular}


was close to 45 degrees. The Bland-Altman plots revealed that in each paired comparison, the mean difference of the expression values found in the sampling methods was close to 0 in each paired comparison and the difference values were within the narrow concordance limits (limits of agreement-LOA); there was no trend showing that the difference changed as the values changed; the difference remained consistently low even when the values changed.

The levels of concordance between the sampling methods were calculated with reference to the PDL1 expression values that were found. A good degree of concordance in terms of PD-L1 expression values was observed between all sampling methods in paired comparisons [Lin's correlation coefficient: pc was 0.9371 (Cl: 0.9081-0.9572)] for the concordance between TTSB, $0.9522(\mathrm{Cl}: 0.9301-0.9675)$ for the concordance

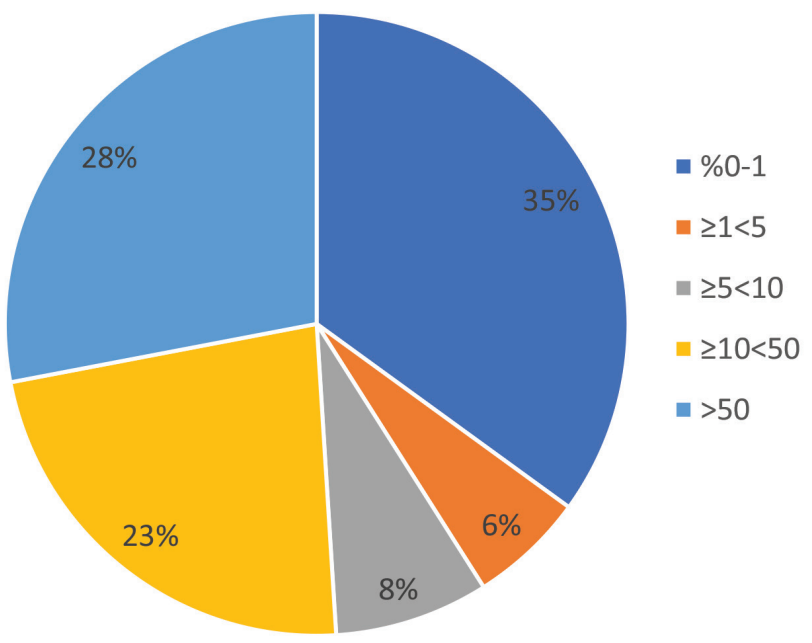

Figure 2. General programmed death-ligand 1 expression

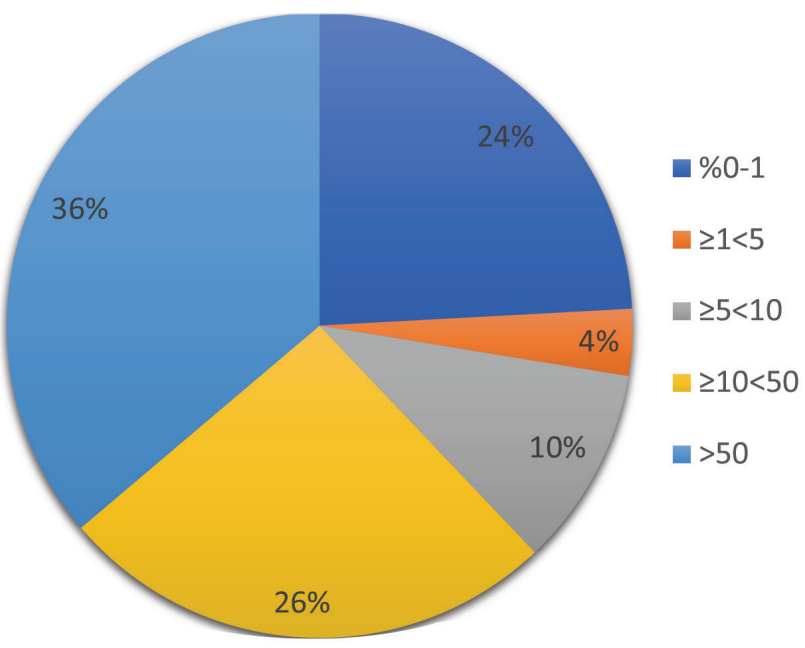

Figure 3. Programmed death-ligand 1 expression in squamous cell carcinoma between TT-CB and 0.9689 [(Cl: 0.9542-0.9789) for the concordance SB-CB)]. The Cronbach's alpha correlation coefficient for the concordance between all the three methods was calculated to be 0.9837 (Cl: 0.977-0.989), which indicates a good level of concordance.

The concordance was also analyzed based on the results obtained through classification of the expression values. All methods revealed the same expression values in 77 samples. In the other 23 samples, the expression values were different from the others in at least one sampling method.

The concordance of the sampling methods with each other was analyzed with respect to their expression values in pairs. A very good concordance between the sampling methods was observed in this analysis [(Weighted Kappa level was 0.8865 (SE: 0.0306, Cl: 0.8264-0.9466)] for the TT-SB comparison, 0.8637 (SE: 0.033, Cl: 0.7989-0.9285) for the TT-CB comparison and 0.8916 (SE: $0.0272, \mathrm{Cl}$ : 0.8383-0.9449) for the SB-CB comparison). Even when the three sampling methods were assessed together, there was a good concordance among them (Fleiss' Kappa: 0.7823 (SE: 0.0326, Cl: 0.7184-0.8463).

The factors that may affect the concordance of the sampling methods were analyzed. For this, the correlation of the differences in the expression values found in each pair of sampling methods with the variables was explored. Further, the same exploration was repeated by making the expression groups ordinal and finding the difference between the rates obtained from the sampling methods (Table 4).

Through this analysis, it was observed that although significant, a weak difference occurred only between the expression rates of TT and $\mathrm{CB}$ and a stronger difference between the expression rates found in the two methods

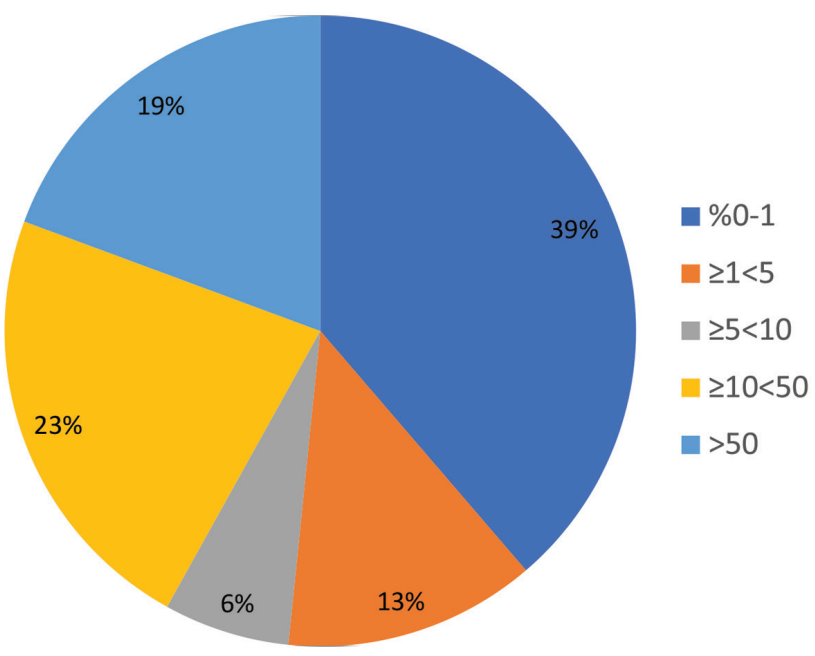

Figure 4. Programmed death-ligand 1 expression in adenocarcinoma 
in squamous cell carcinomas than in adenocarcinomas $(r=0.2, \quad p=0.04)$; this difference found between the expression rates in the two methods increased as the tumor diameter increased $(r=0.2, p=0.045)$. Similarly, the difference between the expression rates in the two methods decreased as the $\mathrm{N}$ stage advanced ( $r=0.22$, $p=0.03$ ).

\section{Conclusion}

The PD-L1 expression is critically important in lung cancer checkpoint inhibitory therapy. The identification of PD-L1 in tumor cells is standardized using immunohistochemical methods (6). The coding of the selected tissue at a preanalytical stage, fixation, processing, section thickness, determination of priorities in molecular and immunohistochemical analyses, selection of PD-L1 clone at the analytic stage, and the correct methods of conducting assessments and quality control have been specified in practice $(7,8)$. The use of different PD-L1 clones has also been shown in non-small cell lung cancer $(9,10)$. In fact, the administration of immunotherapy according to the threshold values of the expression has created a new vision in the treatment of non-small cell lung cancer.

The aim in determining the treatment option is the presence and rating of an in vitro PD-L1 expression in the TT. In this study, the presence of expression was explored in tissues that were sampled using different methods from the same tumor. Instead of taking samples from the tumor resection tissue through the microarray method, three different tissues that were taken simultaneously but separately from the same tumor were examined. Although studies comparing the expression in tumor anatomic resection tissue in the samples taken by way of endoscopic biopsy, transthoracic fine needle aspiration and mediastinoscopic lymph node biopsy are available, in this study, the concordance of expression was found to be very high in the tissue samples (11). As a result, it was found that $C B$ representing the tumor and limited tissue samples give correct and reliable results in the assessment of PDL1 expression. Moreover, there are also studies comparing the expression value in tumor cells in biopsy and resection samples $(12,13)$. In fact, the presence of immune reaction varying across regions in tumors is a known fact (14). A study conducted by Munari et al. (15) has shown that the minimum amount of tissue should be 3-4 pieces of core biopsies for a maximum yield. The concordance was found to be $92.4 \%$ at an expression score of $1 \%$ and over, but there was a marked difference in stratified score groups (16). Further, SB samples were argued not to be sufficient for assessment due to strikingly non-concordant results. The reason for these different results obtained from the methods may be the combination of the intensity of membranous staining and the proportion of tumor cells showing positivity. On the other hand, the presence of a weak concordance can be associated with the chosen PDL1 clone (11). Similarly, the presence of expression in the same cell can vary in the pre-and post-chemotherapeutic stages (17). In fact, mucinous adenocarcinoma and signet-ring cell carcinoma also involve difficulties in the assessment of expression.

Table 3. Frequency of programmed death-ligand 1 expression values by sample types and their distribution

\begin{tabular}{|c|c|c|c|c|c|c|c|}
\hline \multirow[t]{2}{*}{ Sample type } & \multicolumn{7}{|c|}{ Expression values } \\
\hline & $<1(\%)$ & $\geq 1<5(\%)$ & $\geq 5<10(\%)$ & $\geq 10<50(\%)$ & $>50(\%)$ & Median & IQR \\
\hline Tumor tissue & 39 & 7 & 8 & 21 & 25 & 3 & $1-4.75$ \\
\hline Small biopsy & 39 & 10 & 6 & 19 & 26 & 3 & $1-5$ \\
\hline Cell block & 36 & 5 & 12 & 22 & 25 & 3 & $1-4.75$ \\
\hline
\end{tabular}

Table 4. The difference between the expression values and histpathologic parameters

\begin{tabular}{|c|c|c|c|c|c|c|c|c|}
\hline \multicolumn{3}{|l|}{ Histologic type } & \multicolumn{2}{|l|}{ Grade } & \multicolumn{2}{|c|}{ Diameter } & \multicolumn{2}{|c|}{ N status } \\
\hline PD-L1 expression values & CC & p & CC & $\mathbf{p}$ & CC & $\mathbf{p}$ & CC & $\mathbf{p}$ \\
\hline TT-SB & -0.03 & 0.74 & 0.03 & 0.79 & 0.16 & 0.10 & -0.09 & 0.35 \\
\hline TT-CB & -0.2 & 0.04 & -0.06 & 0.62 & 0.2 & 0.045 & -0.22 & 0.03 \\
\hline SB-CB & -0.11 & 0.29 & -011 & 0.29 & 0.014 & 0.89 & -0.14 & 0.17 \\
\hline \multicolumn{9}{|l|}{ PD-L1 expression group } \\
\hline TT-SB & -0.019 & 0.85 & -0.02 & 0.82 & 0.11 & 0.26 & -0.009 & 0.93 \\
\hline TT-CB & -0.09 & 0.38 & -0.02 & 0.87 & 0.16 & 0.11 & -0.09 & 0.37 \\
\hline SB-CB & -0.10 & 0.31 & 0.006 & 0.95 & 0.07 & 0.48 & -0.10 & 0.31 \\
\hline
\end{tabular}



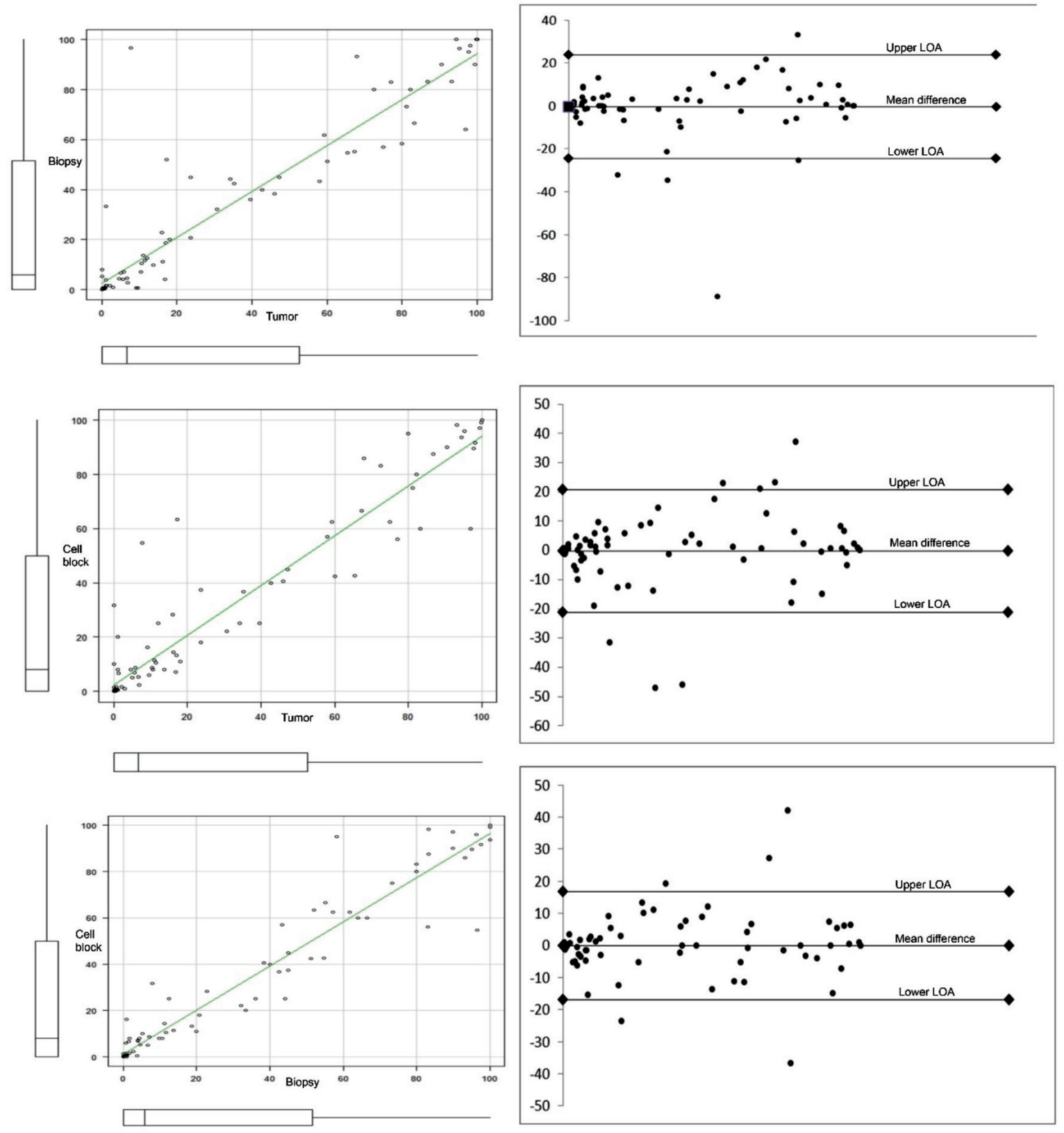

Figure 5. Concordance between samples

LOA: Limits of agreement

PD-L1 expression has been explored in poorlydifferentiated lung cancers. The expression rate was found to be over $90 \%$ in pleomorphic carcinoma (18). The reaction is present more evidently in the sarcomatoid component of the tumor than in its carcinoma component. Along with adenocarcinoma, squamous cell carcinoma and neuroendocrine tumors, this study also considered pleomorphic carcinoma and adenosquamous cell carcinoma. The expression appeared at a rate of $2 / 3$

in these tumors. Although the result of this study would require further support by further studies, it helps in creating an immunotherapy option in poorly-differentiated non-small cell lung cancer with a high probability.

The diameter, as one of the tumor parameters, was included in this study to create a difference, although insignificantly, in the expression between TT and CB. Accordingly, cytological samples may represent the PD-L1 expression lesser than expected because of the diameter 
in T3 and T4 tumors. In a study conducted by Sakata et al. (19), the EBUS needle aspiration was compared to tumor resection. This is supported by the fact that cytological samples are less sensitive than large tissues. However, this difference can be eliminated by combining needle aspiration with tru-cut biopsy.

The PD-L1 expression does not show any difference among tissues sampled using different methods in nonsmall cell lung cancer. It can also be concluded that small biopsies and cytological samples with completed CB are able to represent the tumor itself. However, it should be noted that the tumor parameters may have an effect on expression.

\section{Authorship Contributions}

Concept: H.N.Ü. Design: H.N.Ü. Data Collection or Processing: H.N.Ü, L.C., M.A.B. M.Z.G. Analysis or Interpretation: H.N.Ü. Literature Search: H.N.Ü. Writing: H.N.Ü.

Conflict of Interest: The authors declare that they have no conflict of interest.

Financial Disclosure: This study was supported by the Health Sciences University BAP department.

\section{References}

1. Mahoney KM, Atkins MB. Prognostic and predictive markers for the new immunotherapies. Oncology (Williston Park) 2014;28 Suppl 3:39-48.

2. Bernicker E. Biomarker Testing in Non-Small Cell Lung Cancer: A Clinician's Perspective. Arch Pathol Lab Med 2015;139:44850.

3. Hofman P. PD-L1 immunohistochemistry for non-small cell lung carcinoma: which strategy should be adopted? Expert Rev Mol Diagn 2017;17:1097-108.

4. Ilie M, Hofman V, Dietel M, Soria JC, Hofman P. Assessment of the PD-L1 status by immunohistochemistry: challenges and perspectives for therapeutic strategies in lung cancer patients. Virchows Arch 2016;468:511-25.

5. Sholl LM, Aisner DL, Allen TC, et al. Programmed Death Ligand-1 Immunohistochemistry-A New Challenge for Pathologists: A Perspective From Members of the Pulmonary Pathology Society. Arch Pathol Lab Med 2016;140:341-4.

6. Tsao MS, Kerr KM, Kockx M. PD-L1 immunohistochemistry comparability study in real-life clinical samples: Results of blueprint phase 2 project. J Thorac Oncol 2018;13:1302-11.

7. Cree IA, Booton R, Cane P, et al. PD-L1 testing for lung cancer in the UK: recognizing the challenges for implementation. Histopathology 2016;69:177-86.
8. Sacher AG, Gandhi L. Biomarkers for the Clinical Use of PD-1/ PD-L1 Inhibitors in Non-Small-Cell Lung Cancer: A Review. JAMA Oncol 2016;2:1217-22.

9. Cagle PT, Bernicker EH. Challenges to biomarker testing for PD-1/PD-L1 checkpoint inhibitors for lung cancer. Arch Pathol Lab Med 2015;139:1477-8.

10. Kerr KM, Hirsch FR. Programmed Death Ligand-1 Immunohistochemistry: Friend or Foe? Arch Pathol Lab Med 2016;140:326-31.

11. llie M, Long-Mira $E$, Bence $C$, et al. Comparative study of the PD-L1 status between surgically resected specimens and matched biopsies of NSCLC patients reveal major discordances: a potential issue for anti-PD-L1 therapeutic strategies. Ann Oncol 2016;27:147-53.

12. Heymann JJ, Bulman WA, Swinarski D, et al. PD-L1 expression in non-small cell lung carcinoma: Comparison among cytology, small biopsy, and surgical resection specimens. Cancer Cytopathol 2017;125:896-907.

13. Li C, Huang C, Mok TS, et al. Comparison of 22C3 PD-L1 Expression between Surgically Resected Specimens and Paired Tissue Microarrays in Non-Small Cell Lung Cancer. J Thorac Oncol 2017; 12:1536-43.

14. Gniadek TJ, Li QK, Tully E, Chatterjee S, Nimmagadda $\mathrm{S}$, Gabrielson E. Heterogeneous expression of PD-L1 in pulmonary squamous cell carcinoma and adenocarcinoma: implications for assessment by small biopsy. Mod Pathol 2017;30:530-8.

15. Munari E, Zamboni G, Lunardi G, et al. PD-L1 Expression Heterogeneity in Non-Small Cell Lung Cancer: Defining Criteria for Harmonization between Biopsy Specimens and Whole Sections. J Thorac Oncol 2018;13:1113-20.

16. Kitazono S, Fujiwara $Y$, Tsuta $K$, et al. Reliability of Small Biopsy Samples Compared With Resected Specimens for the Determination of Programmed Death-Ligand 1 Expression in Non-Small-Cell Lung Cancer. Clin Lung Cancer 2015;16:38590.

17. Sheng J, Fang W, Yu J, et al. Expression of programmed death ligand-1 on tumor cells varies pre and post chemotherapy in non-small cell lung cancer. Sci Rep 2016;6:20090.

18. Kim S, Kim MY, Koh J, et al. Programmed death-1 ligand 1 and 2 are highly expressed in pleomorphic carcinomas of the lung: Comparison of sarcomatous and carcinomatous areas. Eur J Cancer 2015;51:2698-707.

19. Sakata KK, Midthun DE, Mullon JJ, et al. Comparison of Programmed Death Ligand-1 Immunohistochemical Staining Between Endobronchial Ultrasound Transbronchial Needle Aspiration and Resected Lung Cancer Specimens. Chest 2018;154:827-37. 